\title{
УДК: 551.312:556.55
}

\section{ТАКСОНОМИЧЕСКОЕ РАЗНООБРАЗИЕ ДИАТОМОВЫХ КОМПЛЕКСОВ ГОЛОЦЕНОВЫХ ДОННЫХ ОТЛОЖЕНИЙ МАЛЫХ ВОДОЕМОВ ДЕПРЕССИИ ОЗЕРА ИМАНДРА}

\author{
А.Л. Косова ${ }^{1}$, Д.Б. Денисов ${ }^{1}$, С.Б. Николаева ${ }^{2}$ \\ ${ }^{1}$ Институт проблем промышленной экологии Севера и ${ }^{2}$ Геологический институт, Кольский научный центр РАН, \\ Anamumbl, Россия \\ Эл. почта: annkosova1976@yandex.ru
}

Статья поступила в редакцию 20.03.2020; принята к печати 05.06.2020

Исследования таксономического разнообразия диатомовых водорослей в голоценовых донных отложениях двух малых водоемов на западном побережье оз. Бабинская Имандра (Мурманская область) продемонстрировало исторические трансформации видового состава и структуры диатомовых комплексов в ответ на меняющиеся условия окружающей среды в голоцене. Изученные водоемы характеризовались доминированием бентосных форм и обрастателей в составе палеосообществ на протяжении всего голоцена. Наиболее резкие изменения в диатомовых комплексах были вызваны тектоническим событием в зоне Имандровской депрессии.

Ключевые слова: диатомовый анализ, палеореконструкиии, голоцен, малые водоемьл, Мурманская область.

TAXONOMIC DIVERSITY OF DIATOM COMPLEXES OF HOLOCENE BOTTOM SEDIMENTS OF SMALL WATER BODIES WITHIN THE LAKE IMANDRA DEPRESSION

A.L. Kosova ${ }^{1}$, L.B. Denisov ${ }^{1}$, S.B. Nikolayeva ${ }^{2}$

${ }^{1}$ Institute of Northern Environmental Problems and ${ }^{2}$ Geological Institute, Kola Research Center, Russian Academy of Sciences, Apatity, Russia

E-mail: annkosova1976@yandex.ru

A study of the taxonomic diversity of diatom algae in Holocene bottom sediments of two small water basins at the western coast of the lake Babinaskaya Imandra (Murmansk Region) has demonstrated the historical transformations of the species compositions of structures of diatom complexes associated with environmental changes in the Holocene. The water basins studied featured the predominance of the benthic and adhesive algae in the algal communities throughout the Holocene. The most drastic changes in the diatom complexes were associated with a tectonic event nearby the Imandra depression.

Keywords: diatom analysis, paleontological reconstruction, Holocene, small water basins, Murmansk Region

\section{Введение}

Таксономическое разнообразие, выраженное в видовом (флористическом) богатстве и соотношении таксонов разного ранга, является одной из важнейших характеристик биологических сообществ. Оно отражает происхождение и эволюционный статус экосистем и обеспечивает их стабильность, хотя функциональное значение биоразнообразия как одного из механизмов устойчивости биоценозов признается недостаточно обоснованным [1]. Особый интерес представляет биоразнообразие арктических и субарктических областей $[33,36]$.

Диатомовые водоросли - традиционный инструмент биоиндикации состояния водных экосистем. Таксономическое разнообразие играет в нем ключевую роль. Диатомовый анализ донных отложений (ДО) имеет важное значение для палеоэкологических реконструкций в высоких широтах. В настоящее время он входит в группу руководящих методов, применяемых для реконструкции исторической динамики окружающей среды и климата [26, 35]. Надежность результатов палеоэкологических реконструкций определяется полнотой данных о региональном флористическом богатстве диатомовых водорослей, поэтому инвентаризация видового состава и уточнение экологических характеристик диатомей является важнейшей научной задачей.

Современные изменения сообществ пресноводных диатомей арктической зоны в ответ на долговременное антропогенное загрязнение и потепление климата не могут быть в полной мере оценены без знаний исторической динамики видового разнообразия. Изучению биогеографических особенностей и филогенетическим исследованиям пресноводных диатомей различных регионов мира в настоящее время уделяется большое внимание [28]. Данные о составе диатомовых комплексов в голоценовых озерных отложениях Мурманской области, используемые для палеогеографических построений, представлены в работах разных лет $[4,7,10,17,18,21]$.

Озеро Имандра является одним из крупнейших водоемов арктической зоны РФ и важнейшим источником водных ресурсов, определяющим функционирование промышленного кластера в Мурманской области. Разработка и освоение месторождений минерального сырья на берегах озера начались в 1930-1940 гг. и привели к появлению комплекса негативных явлений и загрязнению водоема, что в конечном итоге снижает потенциал дальнейшего развития региона. Несмотря на широко 
развернувшиеся исследования экосистемы озера Имандра $[9,14]$ и придаточных водных систем $[15,20]$, биологическое разнообразие диатомовых водорослей изучено недостаточно [24]. Это в полной мере относится к плейстоцен-голоценовым диатомовым комплексам в бассейне озера Имандра, информация о которых необходима для понимания процессов послеледникового формирования экосистемы водоема, условий формирования качества вод и реконструкции палеогеографических обстановок.

Цель данной работы - изучение динамики видового разнообразия диатомовых комплексов донных отложений малых водоемов депрессии озера Имандра в голоцене.

\section{Материалы и методы}

Материалом для исследования диатомовых водорослей послужили донные отложения двух малых озер, расположенных в гляциальной области севера Европейской России, в пределах Балтийского (ФенноСкандинавского) кристаллического щита. Формирование рельефа и озерности этой области обусловлено распространением осадочного чехла. Безымянные озера 1 и 2, выбранные в качестве исследований, находятся в юго-западной части Кольского региона на западном побережье озера Бабинская Имандра и расположены на расстоянии около 3 км друг от друга (рис. 1А). Здесь развиты плоские аккумулятивные террасы, иногда разделенные ледниковыми возвышенностями, долинами и понижениями рельефа, часто занятыми озерами. В одном из таких понижений находится бессточное озеро 1, южный берег которого вытянут на 0,35 км в субширотном направлении. Берега озера заболочены. Котловина озера 2 имеет узкую вытянутую на 1,2 км форму при ширине 0,3-0,5 км (рис. 1 Б). Озеро проточное, берега озера песчано-каменистые, частично заболоченные.

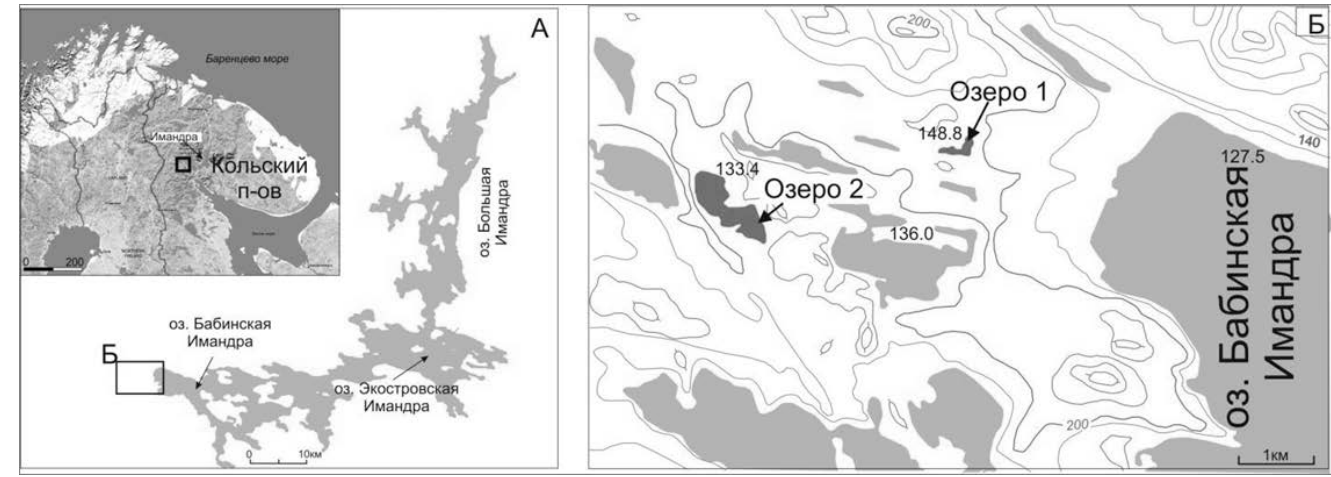

Рис. 1. Схема расположения района исследования (A) и положение изученных озер 1 и 2 с абсолютной отметкой уреза воды 148,8 м и 133,4 м соответственно (Б). Горизонтали рельефа на рис.Б проведены через 50 м.

Отбор колонок донных отложений производился сотрудниками ГИ КНЦ РАН в летний период с катамарана при помощи переносного отечественного поршневого бура. Длина трубки 1 м, диаметр 50 мм. Керны отобраны с перекрытием в несколько сантиметров. Координаты, глубина отбора кернов, их мощности и основные характеристики озер представлены в табл. 1.

Табл.1

Характеристики обследованных озер

\begin{tabular}{|c|c|c|c|c|c|c|}
\hline Озеро & Дата отбора & Координаты & Высота над у. м., м & Глубина, м & Площадь зеркала, км² & Мощность керна, м \\
\hline 1 & август 2013 г & $\begin{array}{c}\text { N 67³2.40'; } \\
\text { E 31 } 31^{\circ} 48.70^{\prime}\end{array}$ & 148,8 & 3,0 & 0,05 & 1,2 \\
\hline 2 & август 2013 г & $\begin{array}{l}\text { N67³1.98'; } \\
\mathrm{E}^{\circ} 1^{\circ} 45.18^{\prime}\end{array}$ & 133,4 & 3,2 & 0,385 & 2,1 \\
\hline
\end{tabular}

Из керна озера 1 были отобраны 9 образцов с интервалом 5 см, из озера 2 - 16 образцов с интервалами 7-10 см. Диатомовые диаграммы, некоторые представители диатомовых водорослей и экологические характеристики диатомовых комплексов показаны на рис. 2-10.

Основной метод исследований - диатомовый анализ. Техническая очистка панцирей диатомей осуществлена по стандартной методике $[3,5]$ с изменениями, разработанными в Институте проблем промышленной экологии Севера КНЦ РАН $[11,12]$. Определение диатомей велось с помощью световых микроскопов Wild Leitz GMBH и Olympus CX 41 при увеличении в 1000 раз с применением иммерсионного объектива. Электронно-микроскопическое исследование проводилось на базе аналитического центра Института геологии Карельского научного центра (г. Петрозаводск) на сканирующем электронном микроскопе (СЭМ) VEGAIILSH при 20 кВ с энергодисперсионным микроанализатором INCA Energy 350. Данные сохранялись 
в виде цифровых изображений в формате JPEG. Bсе обнаруженные в препаратах створки водорослей определяли, по возможности, до внутривидовых таксономических категорий согласно определителям [23, 29-32]. Классификацию уточняли по международной альгологической базе данных [25]. Все препараты, а также очищенный материал створок диатомовых водорослей хранятся в гербарии Института проблем промышленной экологии Севера ФИЦ КНЦ РАН [2].

Дальнейший анализ включал послойное исследование таксономической структуры диатомовых комплексов (ДК) и выявление их относительной численности в пробе по количественной методике, предложенной Н.Н. Давыдовой [3]. Доминантными считали таксоны с численностью более $10 \%$ относительно всего числа учтенных особей; субдоминантными с численностью более 5 , но менее $10 \%$; обычными - от 1 до $5 \%$ включительно; единичными - менее $1 \%$. Доминанты и субдоминанты составляют группу «массовых видов». Рассчитывали содержание створок диатомей (млн) в 1 г воздушно-сухого осадка донных отложений.

Анализ изменения разнообразия диатомей выполнен с использованием общепринятых индексов: Шеннона-Уивера $\left(H^{\prime}\right)$, выравненности по Пиелу $(E)$, доминирования по Симпсону $(C)$, разнообразия по Симпсону $(D)$. Сходство таксономического состава определено между флористическими списками озер с вычислением индекса сходства по Серенсену. Индексы рассчитаны на основе относительного обилия.

Экологическая характеристика видов диатомовых водорослей $[1,5,6,8]$ приведена в соответствии с процентным соотношением створок диатомей в пробе по отношению к солености, местообитанию, $\mathrm{pH}$ воды и географическому распространению.

Проводили анализ толерантности обнаруженных таксонов по отношению к рН и вычисляли интегральное значение $\mathrm{pH}$ для каждого слоя отложений методом [13] по следующей формуле: $\mathrm{pH}=\Sigma p h_{i} \cdot k / \Sigma k$, где $p h_{i}-$ индивидуальное значение $\mathrm{pH}$ для каждого таксона-индикатора; $k$ - показатель обилия (может быть выражен в баллах или значениями численности). В данной работе в качестве показателя $k$ применяли значения численности каждого индикаторного таксона.

Для оценки продуктивности водных экосистем использовали показатель содержания органического вещества (LOI loss on ignition, \%) в осадках водоемов, развивающихся в определенных условиях среды. Он характеризует баланс продукционно-деструкционных процессов в лимносистеме и изменяется в соответствии с географическим положением озерных котловин, их морфологией, колебаниями климата и характером ландшафтов водосбора.

Диаграммыа вертикального распределения массовых и некоторых единичных видов, показателей численности и видового разнообразия диатомовых водорослей в голоценовых осадках построены в программе С2 [27].

Радиоуглеродное датирование выполнено в Лаборатории палеогеографии и геохронологии четвертичного периода факультета географии и геоэкологии СПбГУ в Санкт-Петербурге. Значения календарного возраста приведены на основании калибровочной программы CalPal2007_HULU Кельнского университета 2007 г. (сайт: www.calpal.de).

\section{Результаты}

\section{Литология разрезов донных отложений}

Донные осадки озера 1 представлены коротким разрезом, вскрывшим следующие литологические разности (здесь и далее описание снизу-вверх, глубина указана от поверхности воды): 3,9-3,87 м - песок серый, мелко- и среднезернистый, с органикой. Контакт с перекрывающими осадками неровный, с затеками; 3,87-3,69 м - торф с гиттией и песком; 3,69-3,00 гиттия от слабо слоистой до неясно слоистой (см. рис. 5). Из основания разреза с глубины 3,75-3,85 м получена радиоуглеродная датировка, показавшая возраст $8491 \pm 109$ календарных лет (кал) (ИГАН 4548) [15].

В разрезе озера 2 вскрыты: 5,33-5,14 м - песок с единичными зернами гравия; 5,14-5,06 м - переслаивание алеврита и мелкозернистого песка; 5,06-4,98 м - алеврит с гиттией; 4,98-4,86 м - гиттия черная с минеральной частью; 4,86-4,30 м - гиттия неяснослоистая, коричневая, с остатками растительности и минеральной частью. Переход в вышележащий слой по прослою серого тонкозернистого песка толщиной 2 мм; 4,30-4,00 м - смесь гиттии, торфа, алеврита, песка, обломков древесины (брекчиевый горизонт); 4,00-3,20 м - гиттия коричневая, неяснослоистая, с минеральной частью и растительными остатками внизу интервала (см. рис. 8). Из этого разреза получены 3 радиоуглеродных датировки; расположение пунктов отбора образцов и калиброванные радиоуглеродные датировки показаны на рис. 8. Присутствие сейсмогенной фации (брекчиевый горизонт) в отложениях озера свидетельствует о более значительной роли тектонической компоненты в районе Имандровской неотектонической впадины [16].

\section{Диатомовый анализ}

Озеро 1 (148,8 м н.у.м.). В ДО озера зарегистрированы 72 таксона, относящихся к 24 родам, 15 семействам, 8 порядкам и 2 классам (рис. 2). В исследуемых диатомовых комплексах ведущее место по количеству таксонов занимают роды Еипотіа (17), Pinnularia (12), Gomphonema (8), Brachysira (6). Распределение видов по родам неравномерно. Численность одно- и двувидовых родов - 18 (75 \% от общего числа родов). Видовое богатство низкое, от 30 до 42 таксонов рангом ниже рода в образце. 


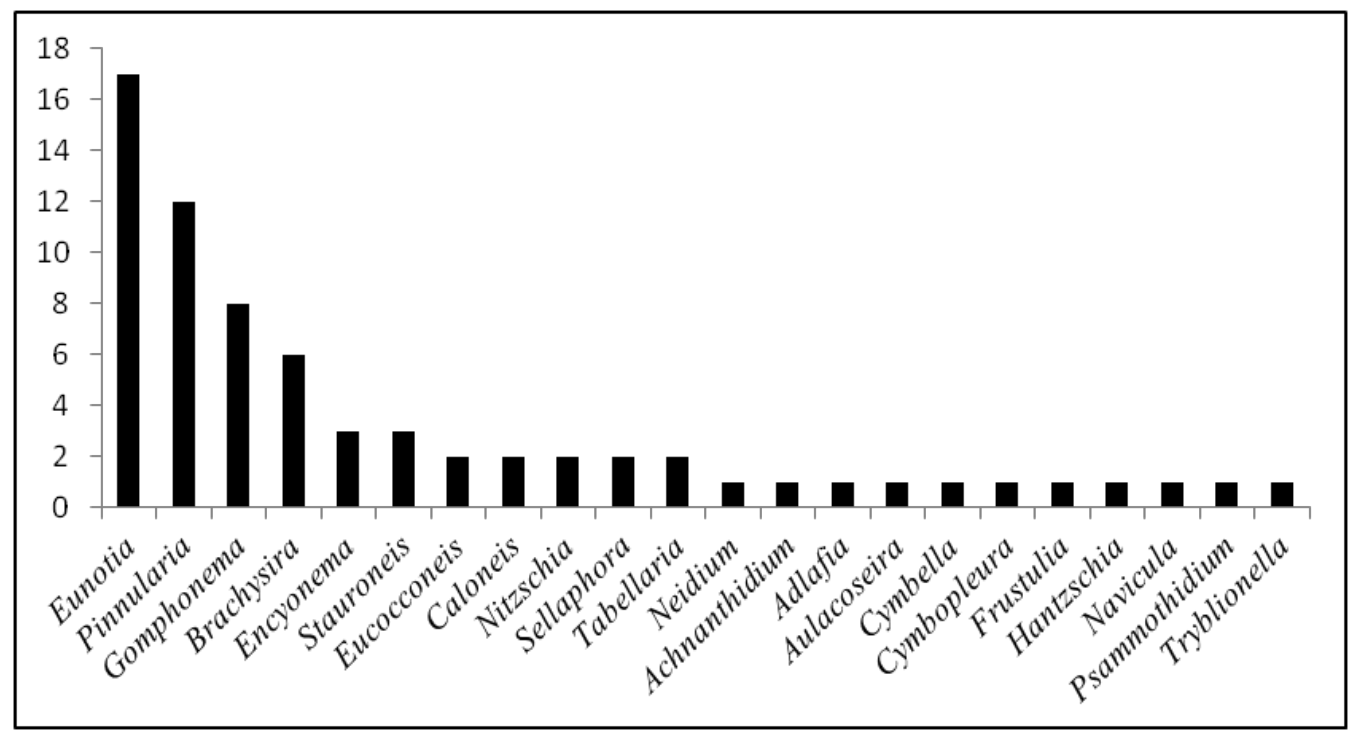

Рис. 2. Распределение числа таксонов диатомей по родам в голоценовых донных отложениях озера 1.

Диатомовая флора представлена типичными пресноводными таксонами (рис. 3).
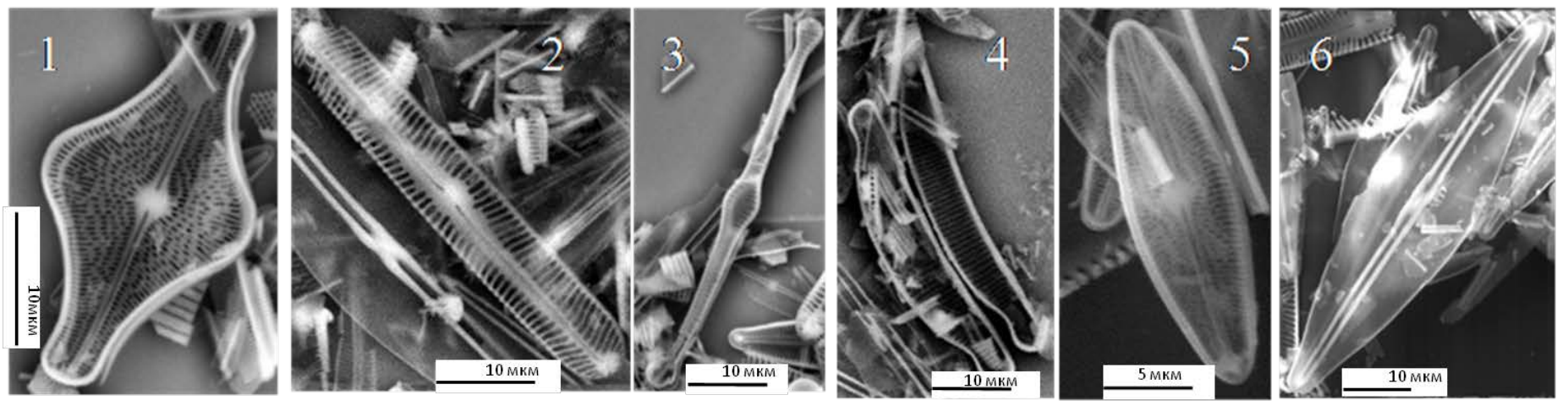

Рис. 3. Некоторые представители диатомовых водорослей из донных отложений озера 1.

1 - Brachysira follis. 2 - Pinnularia bacilliformis. 3 - Tabellaria flocculosa. 4 - Eunotia arcus. 5 - Brachysira brebissonii. 6 - Frustulia rhomboides.

Структура ДК по отношению к содержанию солей в воде характеризуется наибольшим разнообразием видовгалофобов (рис. 4а). Вверх по разрезу отмечается уменьшение доли галофобов с 61 до 41 \% и увеличение доли индифферентных форм до 41\%. Галофилы единично встречаются только в двух образцах ДО. На долю бентосных видов приходится до 93 \% от общего числа створок (рис. 4б). Наиболее характерными видами этой группы являются представители родов Frustulia, Pinnularia, Brachysira. В состав этой группы включены и эпифитные диатомеи рода Еипотіа. Полностью отсутствуют истинно планктонные виды. На долю диатомей, для которых характерно обитание в двух и более экологических нишах, приходится от 5 \% до 19 \%. Наиболее часто из них в пробах с глубины 3,88-3,77 м встречается Tabellaria flocculosa (Roth) Kützing. По отношению к рН (рис. 4в) на долю индикаторной группы ацидофилов приходится до 78\%; изменения их вклада в структуру ДК вверх по колонке не отмечаются. В структуре видов по географической приуроченности наблюдаются изменения от нижних слоев к верхним: виды-космополиты, составляющие до 58\% в нижних слоях, уступают место арктоальпийским видам (рис. 4г). Арктоальпийские виды в основном представлены ацидофилами, по отношению к солености - галофобами.

В ДО озера основная роль принадлежит бентосным формам, таким как Frustulia rhomboides (Ehrenberg) De Toni, представителям родов Brachysira (Brachysira follis (Ehrenberg) R.Ross, Brachysira brebissonii R.Ross), Eunotia и Pinnularia.

Изменения видового состава и структуры ДК по разрезу позволили выделить четыре диатомовые зоны (ДЗ), которые подтверждаются результатами кластерного анализа, выполненного на основе соотношения относительной численности диатомей (рис. 5). 


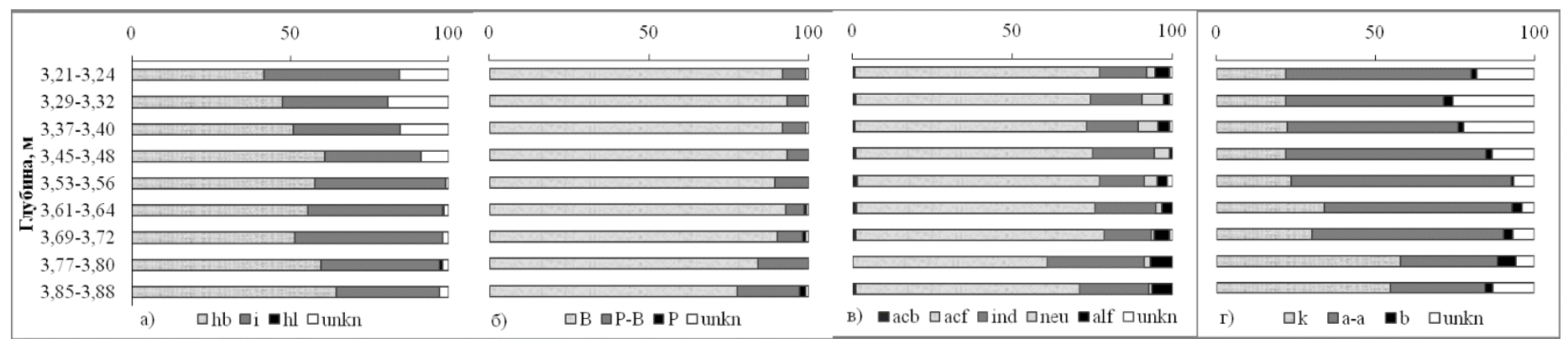

Рис. 4. Экологическая характеристика диатомовых комплексов в донных отложениях озера 1.

$\mathrm{a}$ - соотношение видов по отношению к солености ( $\mathrm{hb}$ - галофобы, i - индифференты, hl - галофилы, unkn - неизвестно). 6 по отношению к местообитанию (В - бентосные, Р-B - планктонно-бентосные, P - планктонные, unkn - неизвестно). в - по отношению к рН воды (acb - ацидобионты, acf - ацидофилы, ind - индифференты, neu - нейтрофилы, alf -алкалифилы, unkn неизвестно). г - географическая приуроченность ( $\mathrm{k}$ - космополиты, a-a - арктоальпийские, $\mathrm{b}$ - бореальные, unkn - неизвестно).

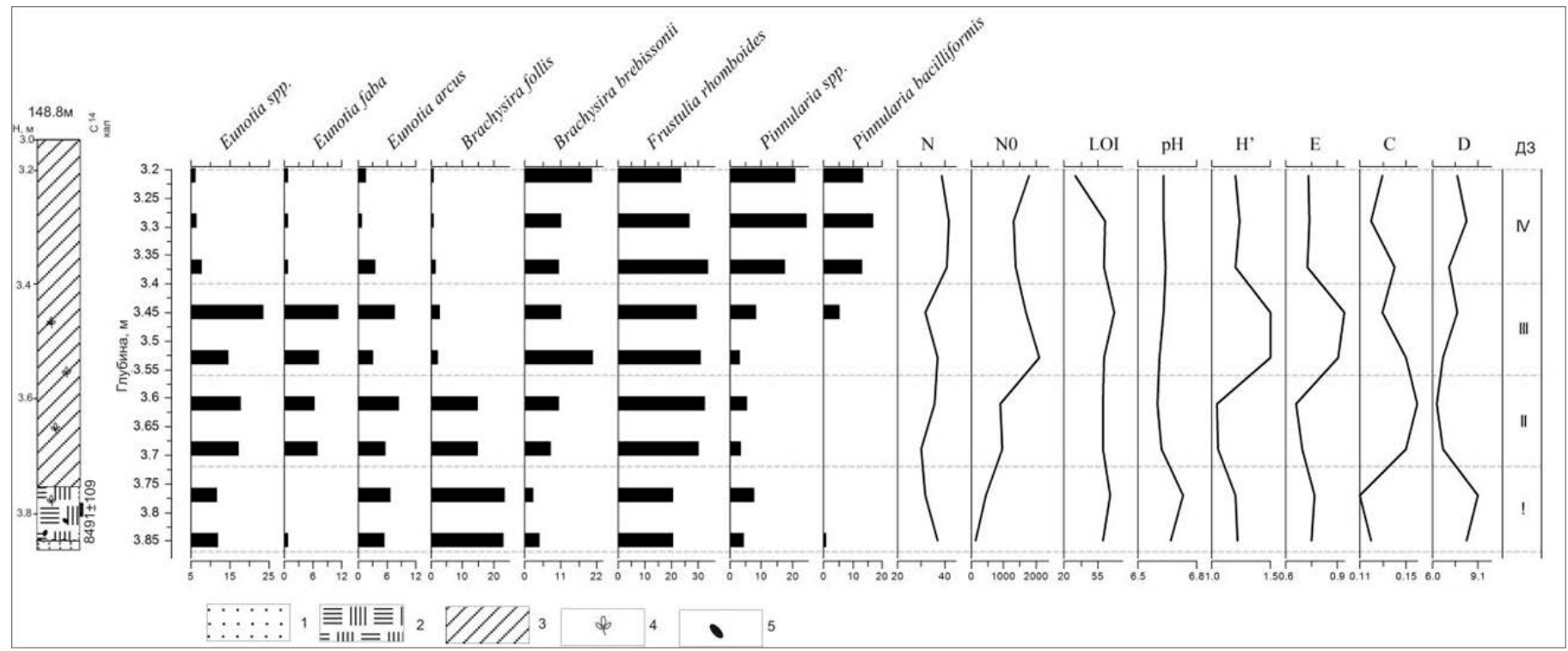

Рис. 5. Литологический разрез и диатомовая диаграмма массовых и индикаторных видов (\%) из донных отложений озера $1 . \mathrm{N}$ - число видов, No - концентрация створок диатомей (млн/г), LOI - потери при прокаливании (\%), pH - значения активной реакции воды, реконструированные по диатомовым комплексам, Н' - индекс Шеннона-Уивера, бит/экз., Е - индекс Пиелу, С - индекс Симпсона, D - индекс разнообразия по Симпсону, ДЗ (I-IV) - основные этапы развития экосистемы водоема по результатам кластерного анализа; 1 - песок, 2 - торф, 3 - гиттия, 4 - макро-остатки растений, 5 - единичные зерна гравия.

Д3 I (3,88-3,72 м) объединяет 2 пробы и характеризуется уменьшением числа видов от 37 до 32, увеличением концентрации створок диатомей (млн/г) от 134 до 450 и содержания органического вещества до $67 \%$, самым высоким значением индекса разнообразия по Симпсону (D) - 9. В составе диатомовых комплексов по численности преобладают бентосные виды Brachysira follis (23\%), Frustulia rhomboides (20 \%) и эпифиты рода Eunotia (13\%), Tabellaria flocculosa (9 \%). Единично отмечен планктонный вид Aulacoseira lacustris (Grunow) Krammer.

ДЗ II (3,72-3,56 м): концентрация створок диатомей возрастает до 946 млн/г, снижается показатель разнообразия по Симпсону $(6,3)$, отмечается самый низкий показатель видового богатства - 30 видов. Индекс выравненности по Пиелу и индекс доминирования по Симпсону отражают доминирование отдельных видов. Доля Frustulia rhomboides достигает 32 \%, в то время как доля Brachysira follis уменьшается до $15 \%$, и к числу доминантов присоединяется Brachysira brebissonii (11 \%). Суммарная численность видов рода Eunotia достигает 18\%, и в роли субдоминанта выступает Eunotia faba (Ehrenberg) Grunow (7 \%) типичный болотный вид северных широт, галофоб. Реконструируемое значение $\mathrm{pH}=6,6$. Большинство компонентов комплекса, представленного ацидофильными, галофобными и арктоальпийскими видами, указывает на слабокислую среду, низкую минерализацию воды, холодные условия развития флоры и заболоченность водосбора. 
Д3 III (3,56-3,40 м) объединяет 3 пробы. Слой 3,53-3,56 м характеризуется максимальной концентрацией диатомовых створок (2098 млн/г) и повышением индекса Шеннона-Уивера до 1,5. Происходит смена доминантов внутри рода Brachysira: вид Brachysira brebissonii (11-21 \%) сменяет Brachysira follis (3\%). Оба вида описаны как типичные ацидофилы, характерные для олиготорофных низкоминерализованных вод. Суммарная численность видов рода Еипотіа достигает в разрезе максимального значения - 27 \%, основной вклад вносят Eunotia faba (7-11\%) и Eunotia arcus Ehrenberg (3-7\%). Отмечается увеличение доли видов рода Pinnularia до $8,6 \%$. В интервале отмечается самое высокое содержание органического вещества (72\%). Эти изменения отражают смену климатических условий.

ДЗ IV (3,40-3,20 м) характеризуется увеличением доли видов рода Pinnularia (17-24\%), в основном за счет Pinnularia bacilliformis K. Krammer (13-17 \%) - эпипелика в мелких олиготрофных водоемах с низким содержанием электролитов. Отмечается уменьшение содержания Frustulia rhomboides к верхним слоям до 24 \%, увеличение Brachysira brebissonii до 21 \%. Brachysira follis в образцах из данного интервала встречается единично. Концентрация диатомей ниже, чем в предыдущей ДЗ. Видовое богатство ДК составляет 39-42 вида в образце, индекс разнообразия по Симпсону выше, чем в ДЗ III. Рассчитанное значение рН составляет 6,6. В слое 3,21-3,24 м отмечается самое низкое содержание органического вещества (31,6 \%).

Реконструируемое значение $\mathrm{pH}$ менялось от 6,61 до 6,73, что соответствует слабокислой среде. В ДО озера 1 отмечено высокое содержание органического вещества (до 72 \%), характерное для болот (рис. 5.).

Озеро 2 (133,4 м н.у.м.). В ДО обнаружены 205 таксонов, относящихся к 58 родам, 31 семейству, 15 порядкам и 3 классам. Наибольшего таксономического разнообразия достигают представители родов Eunotia (16), Pinnularia (15), Cymbella (12), Gomphonema (10) (рис. 6). Численность одно- и двувидовых родов - 32 (или 55 \% от общего числа родов).

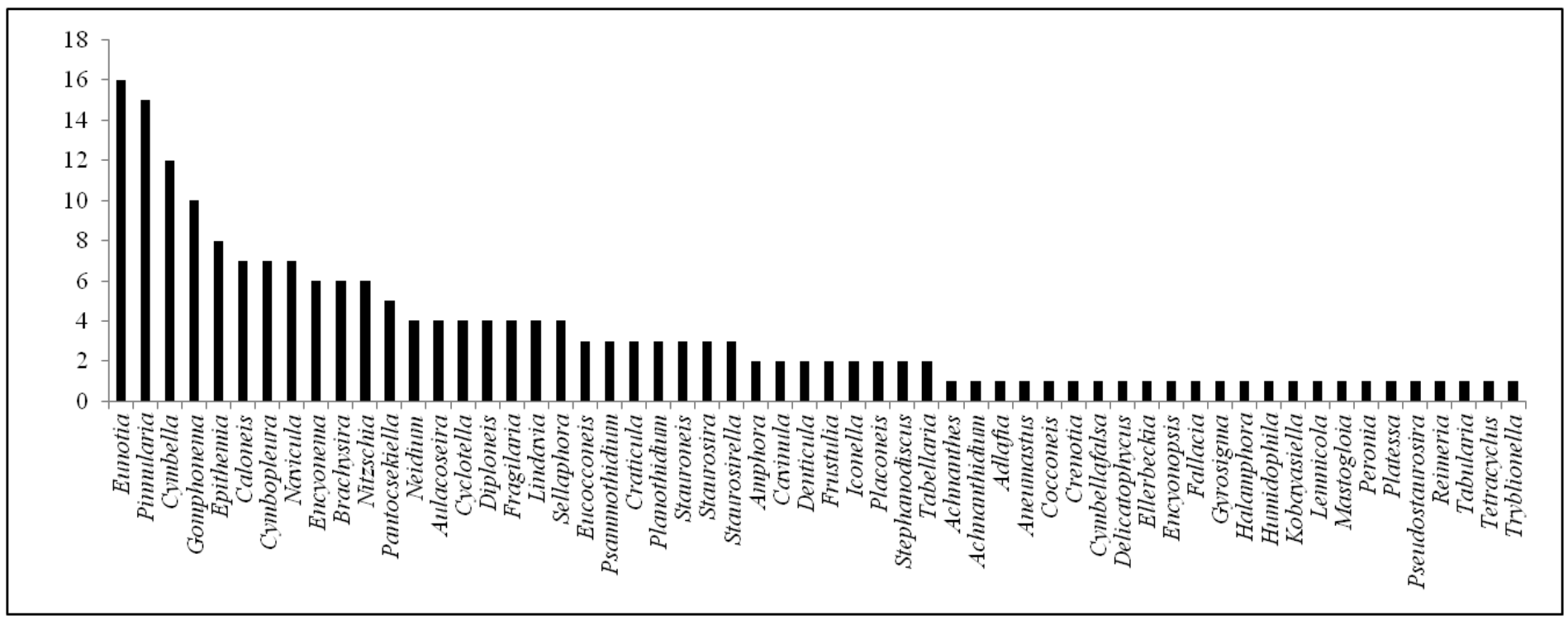

Рис. 6. Распределение числа таксонов диатомей по родам в голоценовых донных отложениях озера 2.

Структура ДК по отношению к солености характеризуется преобладанием видов-индифферентов (рис. 7а). Среди индикаторных диатомей с ограниченным оптимумом по этому фактору галофобы существенно преобладают над галофилами. Доля галофобов на протяжении колонки подвержена значительным колебаниям от 6 до 28 \%. По отношению к местообитанию преобладают бентосные формы (от 47 \% до 89 \%) (рис. 7б). Наибольшее относительное обилие в этой группе приходится на виды рода Brachysira и вид Frustulia saxonica Rabenhorst. Максимальная доля (14 \%) истинно планктонных видов отмечается в образце с глубины 3,90-3,93 м. В исследованных ДК озера 2 по отношению к рН доля индифферентных видов составляет 1/3 на протяжении всей колонки. Соотношение между ацидофилами и алкалифилами вместе с алкалибионтами изменяется от 1:0,4 до 1:1,5 (рис. 7в). Анализ состава ДК в зависимости от географической приуроченности показывает, что больше половины выявленных диатомовых составляют космополиты (35-71 \%) (рис. 7г), что характерно для многих северных регионов. Второе место принадлежит арктоальпийским видам (5-22 \%), но их доля не значительно превышает бореальный комплекс (7-16 \%).

В ДК из пробх с глубин 4,83-4,0 м и 3,67-3,25 м наблюдается монодоминирование - Brachysira zellensis (Grunow) Round \& D.G.Mann. Положение субдоминантов занимают Brachysira vitrea (Grunow) R.Ross и Brachysira brebissonii, численность которых подвержена значительным изменениям от нижних слоев к верхним. По составу ДК было выделено пять ДЗ (рис. 8). 


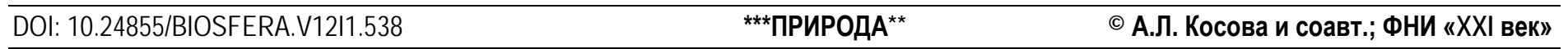

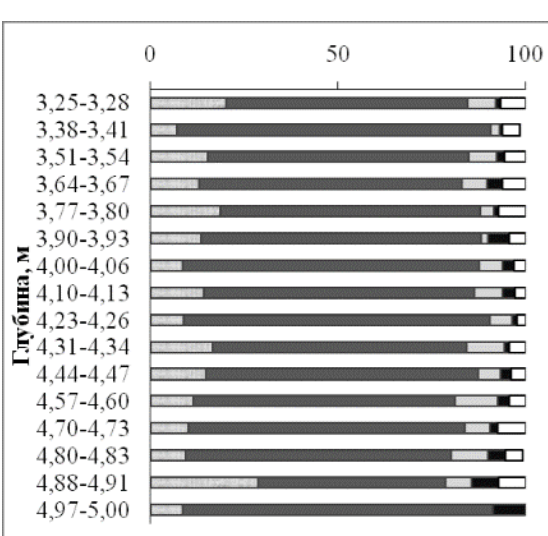

a)
$100 \quad 0$

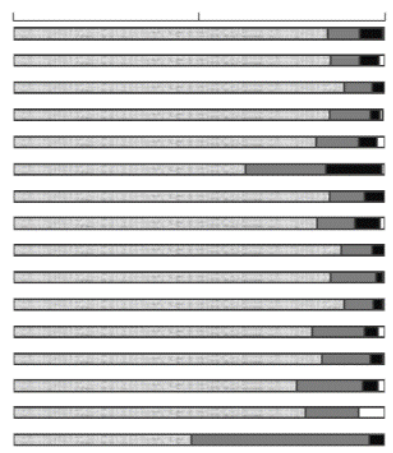

б) $\square \mathrm{B} \square \mathrm{P}-\mathrm{B}=\mathrm{P} \square u n k n$
$100 \quad 0$

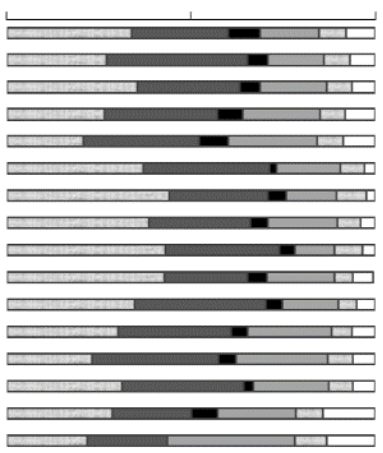

B) $\square$ acf $\mathbf{a}$ ind $\mathbf{m e u} \square$ alf $\square$ alb $\square$ unkn
$100 \quad 0$

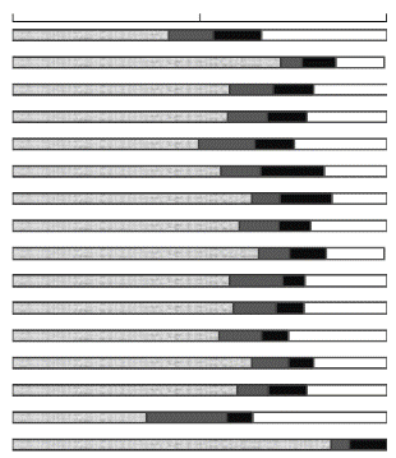

r) $\quad \square \mathrm{k} \square \mathrm{a}-\mathrm{a} \backsim \mathrm{b} \square$ unkn

Рис. 7. Экологическая характеристика диатомовых комплексов в донных отложениях озера 2: а - соотношение видов по отношению к солености (hb - галофобы, i - индифференты, oh - олигогалобы, hl - галофилы, unkn - неизвестно); б - по отношению к местообитанию (В - бентосные, Р-В - планктонно-бентосные, Р - планктонные, unkn - неизвестно); в - по отношению к рН воды (acf ацидофилы, ind . индифференты, neo - нейтрофилы, alf - алкалифилы, alb - алкалибионты, unkn неизвестно); г - географическая приуроченность (k - космополиты, a-a - арктоальпийские, b - бореальные, unkn - неизвестно).

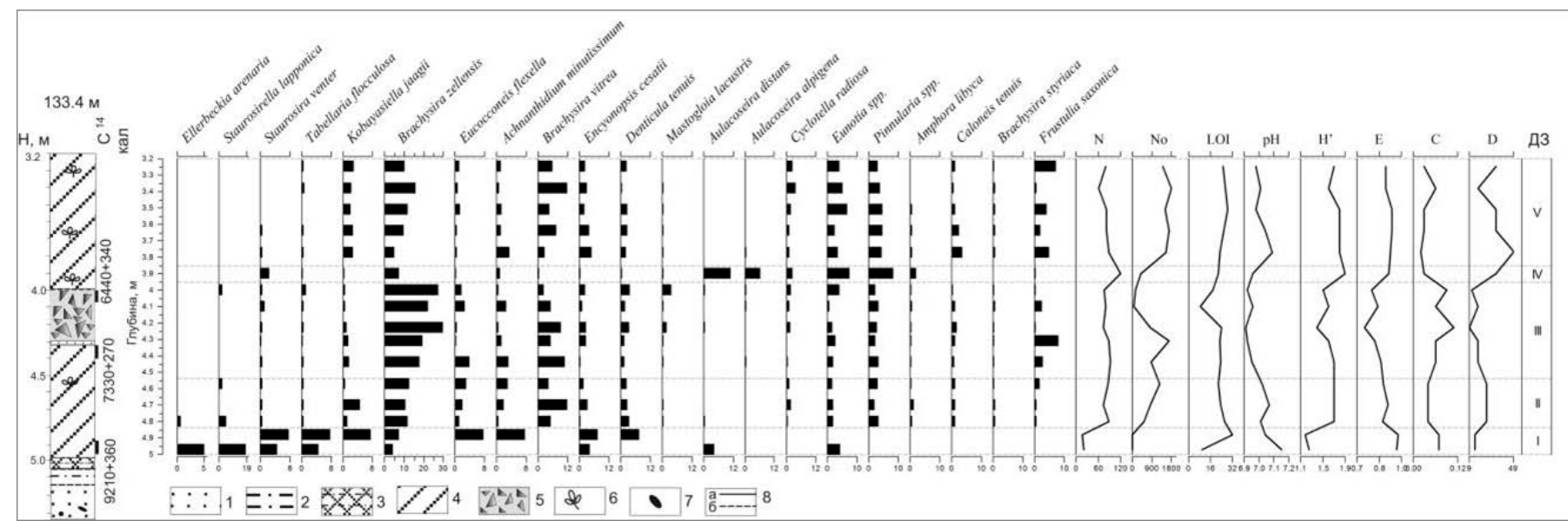

Рис. 8. Литологический разрез и распределение массовых видов диатомовых водорослей в голоценовых осадках озера 2 (\%). $\mathrm{N}$ - число видов, № - концентрация створок диатомей (млн/г), LOI - потери при прокаливании (\%), рН - значения активной реакции воды, реконструированные по диатомовым комплексам, Н' - индекс Шеннона-Уивера, бит/экз., Е - индекс выравненности по Пиелу, C - индекс (мера доминирования C) Симпсона, D - индекс разнообразия по Симпсону, Д3 (I -V) основные этапы развития экосистемы водоема по результатам кластерного анализа; 1 - песок, 2 - алеврит; 3 - гиттия с алевритом; 4 - гиттия; 5 - брекчиевый горизонт; 6 - макро-остатки растений; 7 - зерна гравия; 8 - контакты резкие (а), постепенные (б).

Д3 I (5-4,83 м). В образце 5,00-4,97 м доминанты представлены видом Staurosirella lapponica (Grunow) D.M.Williams \& Round (18\%). В роли сопутствующих видов выступают Staurosira venter (Ehrenberg) Cleve \& J.D.Möller, Staurosira construens Ehrenberg, Ellerbeckia arenaria (Mоore ex Ralfs) R.M.Crawford, Aulacoseira distans (Ehrenberg) Simonsen. Основу ДК составляют бентосные и планктонно-бентосные формы (по 47 \%). По отношению к солености преобладает группа индифферентов (73 \%). Отмечается максимальное для разреза содержание алкалифилов (34 \%) и видов-космополитов (74 \%). Концентрация створок диатомей - 3,7 млн/г, видовое богатство низкое, 20 видов в образце, индекс разнообразия по Симсону 14. Содержание органического вещества в изученной колонке ДО в этом образце самое низкие. С глубины 4,91-4,88 м отмечается увеличение концентрации створок диатомей до 4 млн/г и содержания органического вещества до 31 \%. Увеличивается доля Staurosira venter, Brachysira zellensis, Tabellaria flocculosa (до 7 \%). Появляются Achnanthidium minutissimum (Kützing) Czarnecki, Eucocconeis flexella (Kützing) Meister. Значительно увеличивается доля бентосных форм (79 \%). Изменяется соотношение видов по отношению к солености: уменьшается доля индифферентов за счет увеличения содержания галофилов (14 \%) и галобионтов (28\%). Надо отметить, что это максимальные значения для разреза. Сокращается доля алькалифильных видов, рассчитанное 
значение рН составляет 7,04. В ДК доминанты не отмечены. Индекс Пиелоу равен 1, что указывает на равное соотношение всех видов. ДК этого периода отражает начальный этап формирования водоема. Возможно, на данном этапе развития водоем представлял собой залив палео-Имандры или мелководное озеро олиготрофного типа с нормальной реакцией воды.

ДЗ II (4,83-4,57 м) объединяет 3 пробы. Отмечается увеличение концентрации створок диатомей в отложениях (до 1264 млн/г) и видового богатства (92 вида), индексов Шеннона-Уивера до 1,7 и разнообразия по Симпсону до 25. Доминируют бентосные виды: Brachysira zellensis, B. vitrea. Суммарная численность видов рода Cyclotella колеблется в пределах 1,7-4,5 \%. Отличительной особенностью комплексов является присутствие Mastogloia lacustris (Grunow) Grunow. Рассчитанное значение $\mathrm{pH}$ соответствует нейтральной среде. Содержание органического вещества уменьшается к верхним слоям интервала до $21 \%$.

ДЗ ІІІ (4,57-4,00 м) объединяет 5 проб. Образцы с глубины 4,47-4,44 м и 4,34-4,31 м отобраны из гиттии, а образцы 4,26-4,23 м, 4,13-4,10 м, 4,06-4,00 м - из брекчиевого горизонта. При этом явные отличия видового состава и экологических характеристик ДК не выявлены. Важным признаками изменений условий, произошедших в этот период, является значительное снижение концентрации створок диатомей до 75 млн/г и низкое содержание органического вещества (\%). Индекс разнообразия по Симпсону ниже, чем на начальном этапе формирования водоема. Число видов уменьшается от нижнего слоя интервала к верхнему от 92 до 75. Основная доля, как в ДЗ II, принадлежит бентосным формам. Доминантом является вид Brachysira zellensis (до 30\%), субдоминантом - B. vitrea (до 9\%). Вид Mastogloia lacustris встречается единично, а на глубине 4,06-4,00 м его доля достигает $3,7 \%$.

ДЗ IV (4,00-3,83 м) представлена одной пробой. Доминирует планктонный вид Aulacoseira distans (Ehrenberg) Simonsen (11\%), a A. alpigena (Grunow) Krammer занимает субдоминантное положение (6,5 \%). Увеличивается доля видов рода Еuпоtia $(7,5 \%)$. Изменения видового состава и комплекса доминантов отражают обводнение водоема. Отмечается самое высокое видовое богатство, 120 видов в образце (индекс разнообразия по Симпсону составил 33, индекс Шеннона-Уивера - 1,9). Выявлены 18 видов (15\% от всех выявленных видов), которые обнаружены только в этом интервале. Доля Brachysira zellensis составляет 7\%. Отмечено присутствие Mastogloia lacustris. В структуре видов по географической приуроченности отмечается максимальное содержание бореальных видов (16 \%). Постепенно увеличивается концентрация створок диатомей до 400 млн/г. Реконструируемое значение $\mathrm{pH}$ соответствует околонейтральной реакции воды.

Д3 V (3,83-3,25 м) объединяет 5 проб. Отмечается полная смена доминирующего комплекса. Исчезают виды рода Aulacoseira, доля планктонных форм снижается до 5\%. Вверх по разрезу численность представителей рода Brachysira возрастает, вновь занимая доминирующее положение. Увеличиваются концентрация диатомей и содержание органического вещества (до 25 \%). Отмечается снижение видового богатства. Присутствие Mastogloia lacustris не зафиксировано только в самом верхнем образце с глубины 3,28-3,25 м. Происходящие изменения отражают быстрое уменьшение глубины водоема, заболачивание его берегов.

Из общего списка диатомей, встреченных в ДК, общими для двух озер оказались 53 таксона (23,6 \% флоры), из них в доминирующие комплексы входят Brachysira zellensis, B. brebissonii, B. follis. Общих доминантов нет. Индекс Серенсена равен 0,38. В данном случае можно говорить о низком сходстве таксономического состава голоценовой диатомовой флоры исследуемых озер.

Такое заключение подтверждается кластерным анализом (рис. 9). При сравнении ДК отчетливо выделяются группа А, состоящая из слоев ДО озера 2, и группа Б - из слоев ДО озера 1.

\section{Обсуждение}

Таксономический состав, разнообразие и экологическая структура ДК в двух исследуемых водоемах, расположенных достаточно близко друг к другу, отличаются. Невысокое, по сравнению с озером 2, таксономическое богатство ДК озера 1 , вероятно объясняется малой площадью самого водоема и отсутствием выраженного поверхностного стока, что ограничивало разнообразие условий для развития различных видов диатомей на протяжении голоцена.

По составу и характеру экологических групп ДК изученных озер определяются как пресноводные, характерные для относительно мелководных водоемов. Одним из важнейших показателей флористического богатства является родовой спектр. В обоих водоемах наиболее богаты видами роды Eunotia и Pinnularia (рис. 2, 4), но относительные численности этих родов в составе диатомовых флор значительно различается. Так, в озере 1 доля родов Eunotia и Pinnularia достигает $23 \%$ и $25 \%$, соответственно, тогда как в ДК озера 2 их относительная численность не превышает 7,5 \% и 8,5 \%, соответственно. В озере 1 Frustulia rhomboides доминирует на протяжении всего периода существования водоема, его доля варьирует от $20 \%$ до $33 \%$, тогда как в озере 2 на долю видов рода Frustulia приходится от 0 до 8 \%. Многие виды из родов Eunotia, Pinnularia и Frustulia являются строго пресноводными, небольшое повышение концентрации солей в воде действует на них негативно. Структура ДК по отношению к солености в озере 1 характеризуется преобладанием индикаторной группы видов-галофобов, а в озере 2 преобладают виды-индифференты, и отмечены виды-галофилы. Такие различия указывают на более высокую минерализацию вод в озере 2 . 


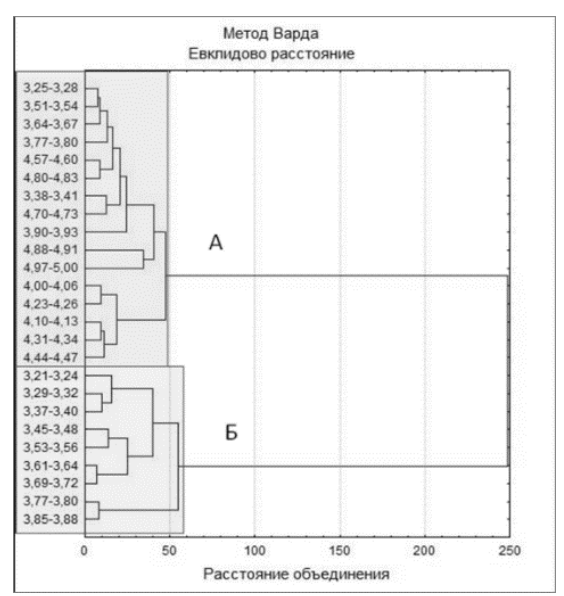

Рис. 9. Кластеры слоев ДО озер по относительной численности видов диатомовых водорослей.

Особый интерес представляет нахождение вида Mastogloia lacustris в составе олигогалобной флоры в осадках озера 2 (рис. 10). Этот вид также обнаружен нами в современных сообществах перифитона олиготрофных озер на северо-западе Мурманской области. Относительно экологии этого вида данные противоречивы. В одних источниках этот вид описывается как алькалифил и эвригалинный мезогалоб, характерный для водоемов, отделившихся от моря [8] или подпитываемых минерализованными трещинными (грунтовыми) водами [22]. В числе массовых видов Mastogloia lacustris отмечен в прибрежной зоне Малого Аральского моря при минерализации 9,12-9,16 \% [19]. В других источниках [5, 34] вид описан как пресноводный. По-видимому, Mastogloia lacustris является видом с широким экологическим оптимумом, который может обитать в среде с низким и высоким содержанием солей. Присутствие Mastogloia lacustris в ДО озера 2 зафиксировано с момента интенсивного накопления органики (глубина 4,83-4,80 м) в первой половине атлантического периода до субатлантического периода. Возможно, развитие данного вида происходило в результате изменения химического состава воды. Озеро расположено в зоне разломов и не исключено, что в него одновременно поступали как трещинные, так и поверхностные воды.
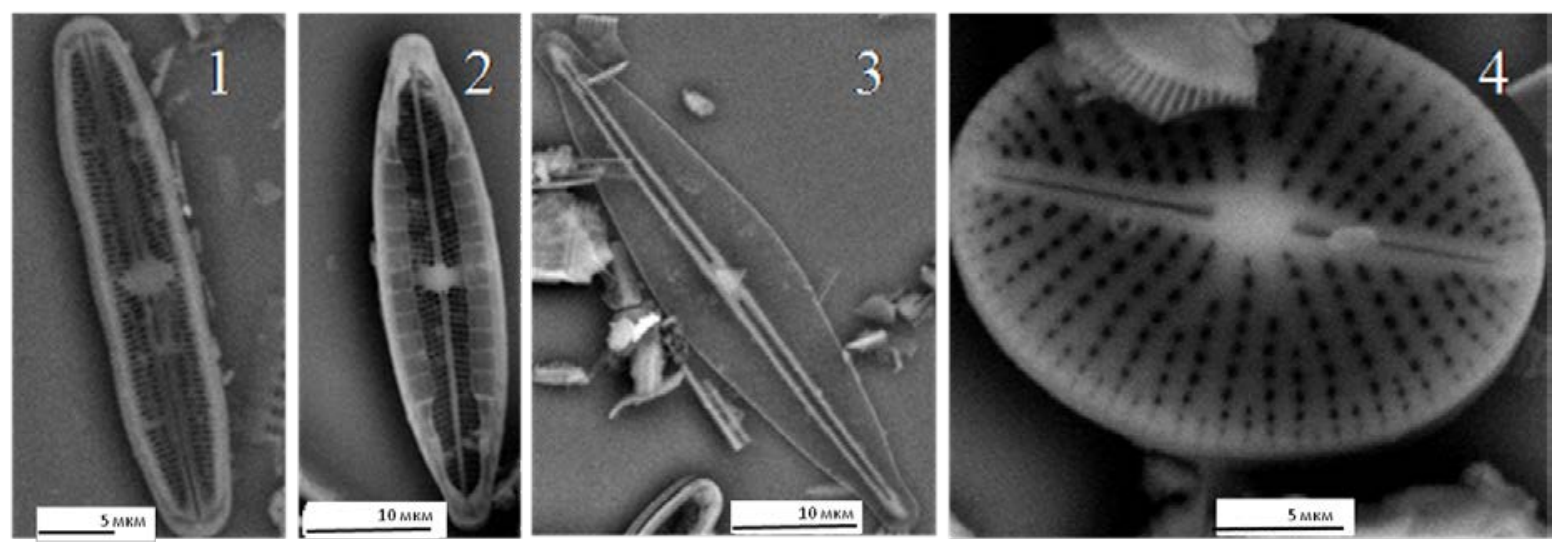

Рис. 10. Некоторые представители диатомовых водорослей из донных отложений озера 2:

1 - Brachysira zellensis. 2 - Mastogloia lacustris. 3 - Frustulia saxonica. 4. - Cavinula pseudoscutiformis.

По отношению к местообитанию в обоих озерах доминирующее положение занимают бентосные формы и обрастатели. В озере 2 отмечены истинно планктонные формы диатомей, что указывает на большую глубоководность, по сравнению с озером 1, где планктонные формы не выявлены. Различаются экологические группы в озерах и по отношению к pH воды. Преобладание алкалифилов вместе с алкалибионтами, значительное количество индифферентных, в том числе циркумнейтральных, диатомей обусловлено нейтральной или слабощелочной реакцией вод в озере 2 , что подтверждают и восстановленные по ДК значения активной реакции воды (рис. 7). При этом высокая доля ацидофильных диатомей в озере 1 отражает слабокислые условия обитания на протяжении всего периода развития водоема, о чем свидетельствуют реконструированные значения $\mathrm{pH}$ (рис. 4). 
В озере 1 ДК имеют олигодоминантный характер, доминанты представлены двумя-тремя видами, характерными для дистрофных озер и болот, на протяжении всей изученной толщи, и их доля изменяется в пределах от $15 \%$ до $33 \%$. В то же время в ДК озера 2 отмечается монодоминирование.

Распределение показателей индекса Пиелоу (Е) в озере 1 изменяется от 0,66 до 0,99 , составляя в среднем 0,79 ; в озере 2 этот показатель варьирует в пределах 0,75-0,98 при средних значений для керна $-0,88$. Несмотря на присутствие массовых видов в озере 1, индекс Пиелоу все же характеризуется высокими значениями, но он ниже, чем в озере 2, в котором отмечено большое число единичных таксонов. Индекс Пиелоу отражает выравненность видов в озере 2.

Показатели меры доминирования по Симпсону (C) в пробах из озера 1 изменяются от 0,11 до 0,16, в среднем - 0,13. В озере 2 этот показатель варьирует в пределах от 0,02 до 0,11 , в среднем составляя 0,05 . наименьшие значения отмечены в пробах из озера 2 , в которых обнаружено наибольшее число видов и разновидностей. Низкие показатели индекса Симпсона также объясняются присутствием большого числа «единичных» видов диатомей и небольшим числом «массовых» видов. В озере 1 среднее значение индекса выше, чем в озере 2, что подтверждает наличие доминирующих видов.

Индекс разнообразия по Симпсону изменяется в таких диапазонах: в озере 1 - от 6,5 до 9,3, в среднем составляя 7,5, в озере 2 - от 9 до 50, в среднем 23,3. Минимальные значения индекса Шеннона-Уивера характерны для образцов с олиго- и монодоминантным составом видов преимущественно из родов Frustulia и Brachysira. Ископаемая диатомовая флора озера 2 характеризуется высоким разнообразием.

Низкое сходство таксономического состава ДК в озерах также указывает на различия условий развития диатомовой флоры.

Судя по характеру ДК озера 1, в котором основная роль принадлежит донным видам из родов Frustulia и Brachysira, способным развиваться преимущественно на мхах, а также высокому содержанию органического вещества в пробах, ДО накапливались в холодном мелководном олиготрофном водоеме со слабокислой средой. Озеро сформировалось на заболоченном участке в начале атлантического времени, а затем происходило постепенное сокращение его площади и глубины. Границы между диатомовыми зонами отражают смену экологических условий обитания диатомовой флоры, при этом не наблюдаются резкие литологические границы. Возможно, в результате увеличения поступления биогенных веществ и снижения минерализации происходит замещение одного вида другим внутри доминантного рода Brachysira. Замещение видов рода Eunotia видами рода Pinnularia (P. bacilliformis), возможно, произошло в результате изменении водности и поверхностного стока, заболачивании водоема в условиях сухого холодного климата [22].

Озеро 2 представляло собой сравнительно мелководный водоем до начала атлантического периода. Состав ДК из брекчиевого горизонта сходен с флорой из нижележащих слоев, что указывает на однородность условий окружающей среды. Резкое снижение общего обилия диатомей связано с поступлением огромного количества терригенного материала с водосборной площади. Богатая диатомовая флора и доминирование планктонных видов, характерных для более крупных озер, наблюдаемая в вышележащем слое, и их последующее исчезновение также свидетельствуют в пользу предположения, что такой характер нарушений вызван эрозией, перемещением и последующим переотложением осадков.

\section{Заключение}

Выявлены значительные различия в таксономической и экологической структуре ДК в голоценовых ДО изученных водоемов. Более значительным видовым богатством характеризуются ДК более крупного озера 2 с выраженным поверхностным стоком. Общей особенностью водоемов является значительная доля бентосных форм и обрастателей в составе палеосообществ диатомей. Разнообразие и выравненность диатомей озерных экосистем могут быть оценены как высокие. В структуре ДК единичные и обычные таксоны выступают основой разнообразия диатомовых водорослей, которое снижается с ростом доли доминантов.

Различия в относительной численности родов Eunotia и Pinnularia, занимающих главные места в родовых спектрах, в соотношении индикаторных групп по отношению к солености отражают разную минерализацию вод в озерах, а также разную степень заболоченности ландшафтов. Большое число таксонов, присутствие планктонных форм в озере 2 позволяет утверждать, что оно было глубже, чем в настоящее время.

Результаты диатомового анализа, сопряженные с данными радиоуглеродного датирования, позволяют выделить основные этапы эволюции водоемов, которые охватывают периоды от бореального до субатлантического времени. Накопление гиттии в озере 2 началось в бореальный период (9300-8000 ${ }^{14} \mathrm{C}$ л. н.). Низкие видовое богатство и содержание органического вещества, присутствие холодолюбивых видов указывают на то, что на начальном этапе накопление осадков происходило в холодноводном олиготрофном водоеме. В атлантический период $\left(8000-4600{ }^{14} \mathrm{C}\right.$ л. н.) формировались более богатые в видовом отношении ДК, увеличились концентрация диатомей и содержание органического вещества, преобладали донные виды и обрастатели. Озеро представляло собой олиготофный, мелководный, хорошо прогреваемый водоем с частично заболоченными берегами. В этот период на основании литологического и диатомового анализов выявлены последствия тектонической активности в зоне Имандровской депрессии. К этому же периоду приурочено формирование озера 1 . В ДК преобладали бентосные виды Frustulia rhomboides, Brachysira follis, B. brebissonii, эпифиты Eunotia spр. Большинство 
компонентов комплекса - ацидофилы, галофобы, арктоальпийские виды, что указывает на изначально кислую среду, низкую минерализацию воды и холодные условия развития флоры. Дальнейшее потепление и увлажнение сопровождалось повышением уровня воды в озере, притоком гуминовых вод, снижением минерализации воды, берега заболачивались, следствием чего явилось увеличение доли Frustulia rhomboides и Eunotia spp., внутри доминантного рода Brachysira один вид вытеснил другой. В суббореальный период (4600-2500 ${ }^{14} \mathrm{C}$ л. н.) продолжает накапливаться гиттия, водоемы мелеют. Признаком дальнейшего зарастания и заболачивания берегов в условиях сухого и холодного климата в озере 1 являются уменьшение доли Eunotia spр и увеличение доли видов рода Pinnularia.

Таким образом, исследование таксономического состава и экологической структуры диатомовых комплексов донных отложений малых водоемов депрессии озера Имандра показало, что они не были постоянными на протяжении голоцена и изменялись под влиянием эволюции палеообстановок. Основными факторами, определявшими развитие диатомовых комплексов, являлись:

1) климатические изменения, обусловившие различные периоды увлажненности;

2) локальные условия, такие как происхождение и строение котловины озера, его глубины, размера, типа бассейна;

3) дифференцированные неотектонические движения и связанные с ними изменения локальных условий осадконакопления.

\section{Благодарности}

Авторы выражают благодарность 3.И. Слуковскому за помощь при работе за электронным микроскопом.

Работа выполнена в рамках Госзадания тем НИР №0226-2015-0001 и № 0226-2019-0054 и частично поддержана грантом РФФИ № 18-05-60125 Арктика.

\section{Список русскоязычной литературы}

\section{ЛИТЕРАТУРА}

1. Баринова СС, Медведева ЛА, Анисимова ОВ. Биоразнообразие водорослей-индикаторов окружающей среды. Тель-Авив: Piles Studio; 2006.

2. Боровичёв ЕА, Денисов ДБ, Корнейкова МВ, Исаева ЛГ, Разумовская АВ, Химич ЮР, Мелехин АВ, Косова АЛ. Гербарий ИППЭС КНЦ РАН. Труды Кольского научного центра РАН. 2018; 9(9-6):179-86.

3. Давыдова НН. Диатомовые водоросли - индикаторы природных условий водоемов в голоцене. Л.: Наука; 1985.

4. Денисов Д.Б. Изменения гидрохимического состава и диатомовой флоры донных отложений в зоне воздействия горнорудного производства (Кольский полуостров). Водные ресурсы. 2007;34(6):719-30.

5. Диатомовый анализ. Кн. 1. Л.: Госгеолиздат, 1949.

6. Диатомовые водоросли СССР. Ископаемые и современные. Т. 1. Л.: Наука, 1974.

7. Евзеров ВЯ, Корсакова ОП, Колька ВВ. История развития морских бассейнов в Беломорской депрессии за последние 130 тысяч лет (состояние вопроса и перспективы исследований). Бюлл. Комиссии по изучению четвертичного периода. 2007;(67):54-65.

8. Каган ЛЯ. Диатомовые водоросли евро-арктического региона. Аннотированная коллекция (древние и современные морские и пресноводные). Апатиты: КНЦ РАН; 2012.

9. Кашулин НА, Беккелунд А, Даувальтер ВА, Петрова ОВ. Апатитовое горно-обогатительное производство и эвтрофирование арктического озера Имандра. Арктика: экология и экономика. 2019;3(35):16-34.

10. Косова АЛ, Денисов ДБ, Николаева СБ. Развитие экосистемы озера Тридцатка (Мурманская область) в голоцене по результатам диатомового анализа донных отложений. Труды Карельского научного центра РАН. 2018 ;(9):77-91.

11. Косова АЛ, Малышева МБ, Денисов ДБ. К методике камеральной обработки проб для диатомового анализа донных отложений. Квартер во всем его многообразии. Фундаментальные проблемы, итоги изучения и основные направления дальнейших исследований: Материалы VII Всероссийского совещания по изучению четвертичного периода (Апатиты, 12-17 сент. 2011 г.). Апатиты; СПб. 2011; 1(А-К): 294-95.

12. Методы экологических исследований водоемов Арктики. Мурманск: МГТУ; 2019.

13. Моисеенко ТИ, Разумовский ЛВ. Новая методика реконструкции катионно-анионного баланса в озерах (диатомовый анализ). ДАН. 2009; 427(1):132-35.

14. Моисеенко ТИ, Денисов ДБ. Возможно ли восстановление озерной арктической экосистемы после длительного загрязнения? Арктика: экология и экономика. 2019;4(36):16-25.

15. Николаева СБ, Лаврова НБ, Толстобров ДС, Денисов ДБ. Реконструкция палеогеографических обстановок голоцена в районе озера Имандра (Кольский регион): результаты палеолимнологических исследований. Труды Карельского научного центра РАН. 2015;(5):34-47.

16. Николаева СБ, Лаврова НБ, Денисов ДБ, Толстобров ДС. Следы катастрофических процессов в донных осадках озер западного побережья озера Бабинская Имандра (Кольский регион). Изв. РГО. 2016;148(4):38-52. 
17. Порецкий ВС, Жузе АП, Шешукова ВС. Диатомовые Кольского полуострова в связи с микроскопическим составом кольских диатомитов. Тр. Геоморфол. ин-та. Кольский диатомитовый сборник. 1934;(8): 95-210.

18. Рубинраут ГС, Каган ЛЯ. О формировании Верхнепонойской и Имандровской депрессий. В кн.: История озер в голоцене. Тез. IV Всесоюз. симпозиума по истории озер. Л.: Институт озероведения АН СССР; 1975. С. 63-8.

19. Сапожников ФВ, Калинина ОЮ, Курбаниязов АК, Юсупов Б, Мухитдинова С. Абдимуталип НА. О состоянии микрофитобентоса водоемов системы Аральского моря по исследованиям комплексной международной экспедиции. Известия Национальной академии наук Республики Казахстан. Серия биологическая и медицинская. 2017;(3):171-6.

20. Толстоброва АН, Толстобров ДС, Колька ВВ, Корсакова ОП. История развития озера Осинового (Кольский регион) в поздне- и постледниковое время по материалам диатомового анализа донных отложений. Труды Карельского научного центра РАН. 2016;(5):106-16.

21. Шилова О.С. Голоценовые диатомеи болот Кольского полуострова и Северо-Восточной Карелии. М.: МАКС Пресс; 2011.

22. Шелехова Т.С. Этапы развития малых озер северо-западной Карелии в голоцене по данным диатомового анализа (на примере озер горы Нуорунен). Вопросы геологии докембрия Карелии. Петрозаводск: КНЦ РАН. 1993: 160-181.

\section{Общий список литературы/ Reference List}

1. Barinova SS, Medvedeva LA, Anisimova OV. Bioraznoobraziye Vodorosley-Indikatotov Okruzhayuschey Sredy. [Biodiversity of Environmental Indicator Algae]. Tel Aviv: Pilies Studio, 2006. (In Russ.)

2. Borovichov YeA, Denisov DB, Korneykova MV, Isaeva LG, Razumovskaya AV, Khimich YuR, Melekhin AV, Kosova AL. [Herbarium of INEP KSC RAS]. Trudy Kolskogo Nauchnogo Tsentra RAN. 2018;9(9-6):179-86. (In Russ.)

3. Davydova NN. Diatomovye Vodorosli - Indikatory Prirodnykh Usloviy Vodoyemov v Golotsene [Diatoms as Indicators of Environmental Conditions of Water Bodies in the Holocene]. Leningrad: Nauka; 1985. (In Russ.)

4. Denisov DB. [Changes in the hydrochemical composition and diatomic flora of bottom sediments in the zone of influence of metal mining production (Kola Peninsula)]. Vodnye Resursy. 2007;34(6):719-30. (In Russ.)

5. Diatomovyj Analiz Kn. 1. [Diatom Analysis. Book 1]. Leningrad: Gosgeolizdat; 1949. (In Russ.)

6. Diatomovye Vodorosli SSSR T. 1 (Iskopaemye i Sovremennye) [Diatoms of the USSR (Fossil and Recent). Vol. 1]. Leningrad: Nauka, 1974. (In Russ.)

7. Yevzerov VYa, Korsakova OP, Kolka VV. [The history of the development of marine basins in the White Sea depression over the past 130 thousand years (the state of the issue and research prospects)]. Biulleten Komissii po Izucheniyu Chetvtvertichnogo Perioda. 2007;(67):54-65. (In Russ.)

8. Kagan L.Ya. Diatomovye Vodorosli Yevro-Arkticheskogo Regiona. Annotirovannaya Kollektsiya (Drevniye i Soveremennye, Morskiye i Presnovodnye [Diatoms of the Euro-Arctic region. Annotated collection (Ancient and Modern; Marine and Freshwater)]. Apatity: Izdatelstvo Kolskogo Nauchnogo Tsentra RAN; 2012. (In Russ.)

9. Kashulin NA, Bekkelund A, Dauvalter V A, Petrova OV. [Apatite mining and processing production and eutrophication of the Arctic Lake Imandra]. Arktika: Ekologiya i Ekonomika. 2019;3(35):16-34. (In Russ.)

10. Kosova AL, Denisov DB, Nikolayeva SB. [The history of Lake Tridsatka (Murmansk region) ecosystem development in the Holocene based on diatom sediment records]. Trudy Karelskogo Nauchnogo Tsentra RAN. 2018;(9):77-91. (In Russ.)

11. Kosova AL, Malysheva MB, Denisov DB. [On the methods of cameral treatment of samples for the diatom analysis of bottom sediments]. In: Kvarter vo Vsem Yego Mnogoobrazii. Fundamentalnye Problemy, Itogi Izucheniya i Osnovnye Napravleniya Dalneyshikh Issledovaniy. Apatity, Saint Petersburg; 2011;1(A-K). P. 294-5. (In Russ.)

12. Metody Ekologicheskikh Issledovaniy Vodoyemov Arktiki. Murmansk: MGTU; 2019. (In Russ.)

13. Moiseyenko TI, Razumovsky LV. [A new technique reconstructing the cationic-anionic balance in lakes (diatom analysis)]. Doklady Akademii Nauk; 2009;427(1):132-5. (In Russ.)

14. Moiseyenko TI, Denisov DB. [Is possible to restore the Arctic lake ecosystems after long-term pollution?]. Arktika: Ekologiya i Ekonomika. 2019;4(36):16-25. (In Russ.)

15. Nikolayeva SB, Lavrova NB, Tolstobrov DS, Denisov DB. [Reconstructions of Holocene paleogeographic conditions in the Lake Imandra area (Kola region): results of paleolimnological research]. Trudy Karelskogo Nauchnogo Tsentra RAN. 2015; (5): 34-47. (In Russ.)

16. Nikolayeva SB, Lavrova NB, Denisov DB, Tolstobrov DS. [Traces of catastrophic processes in the bottom sediments of lakes on the west coast of Lake Babinskaya Imandra (Kola region)]. Izvestiya RGO. 2016;148(4):38-52. (In Russ.)

17. Poretsky VS, Zhuze AP, Sheshukova VS. [Diatoms of the Kola Peninsula as related to the microscopic composition of Kola diatomites]. Trudy Geomorfologicheskogo Institutata Kolskiy Diatomitovyi Sbornik. 1934;(8):95-210. (In Russ.)

18. Rubinraut GS, Kagan LYa. [On the Formation of the Upper Ponoy and Imandrovskaya Depressions]. In: Istoriya Ozer v Golotsene. Leningrad: Institut Ozerovedeniya AN SSSR; 1975. P. 63-8. (In Russ.) 
19. Sapozhnikov FV, Kalinina OYu, Kurbaniyazov AK, Yusupov B, Mukhitdinova S, Abdimutalip NA. [About the condition of the microphytobenthos of reservoirs of the Aral Sea system based on studies carried out by a joint international expedition]. Izvestiya Natsionalnoy Akademii Nauk Respubliki Kazakhstan. Seriya Biologicheskaya i Meditsinskaya. 2017;(3):171-6. (In Russ.)

20. Tolstobrova AN, Tolstobrov DS, Kolka VV, Korsakova OP. [Late Glacial and Postglacial history of Lake Osinovoye (Kola region) inferred from sedimentary diatom assemblages]. Trudy Karelskogo Nauchnogo Tsentra RAN. 2016;(5):106-16. (In Russ)

21. Shilova OS. Golocenovye Diatomei Bolot Kolskogo Poluostrova i Severo-Vostochnoy Karelii [Holocene Diatoms of Bogs of the Kola Peninsula and North-East Karelia]. Moscow: MAKS Press; 2011. (In Russ.)

22. Shelekhova TS. [Stages of the development of small lakes of Northwestern Karelia in the Holocene according to diatom analysis (exemplified with lakes of Mount Nuorunen)]. In: Voprosy Geologii Dokembriya Karelii. Petrozavodsk: KNC RAN; 1993. P. 16081. (In Russ.)

23. An Atlas of British Diatoms. Ed. PA Sims. Bristol; 1996.

24. Denisov DB, Genkal SI. Centric diatom algae of Lake Imandra (Kola Peninsula, Russia). Int J Algae. 2018;20(1):23-32.

25. Guiry MD, Guiry GM. AlgaeBase. World-Wide Electronic Publication. National University of Ireland. Galway, 2019. URL: http://www.algaebase.org.

26. Jacq K. Giguet-CovexCh. Sabatier P. PerretteY, Fanget B, Coquin D, Debret M, Arnaud F. High-resolution grain size distribution of sediment core with hyperspectral imaging. Sedimentary Geology. 2019;393-394: 1-10.

27. Juggins S. C2 Version 1.5 User guide. Software for ecological and palaeoecological data analysis and visualisation. Newcastle University, Newcastle upon Tyne. 2007.

28. Kociolek JP. A worldwide listing and biogeography of freshwater diatom genera: a phylogenetic perspective. Diatom research. 2019; 33;(4):509-34.

29. Krammer K. Cymbella. In: Lange-Bertalot H, ed. Diatoms of Europe. 3. Ruggell: A.R.G. Gantne Verlag K.G; 2002.

30. Krammer K. Cymbopleura, Delicata, Navicymbula, Gomphocymbellopsis, Afrocymbella. In: Lange-Bertalot H, ed. Diatoms of Europe, 4. Ruggell: A.R.G. Gantner Verlag K.G; 2003.

31. Krammer K. The genus Pinnularia. In: Lange-Bertalot H, ed. Diatoms of Europe. 1. Vaduz: A.R.G. Gantner Verlag K.G; 2000.

32. Krammer K., Lange-Bertalot H. Bacillariophyceae - Subwasserflora von Mitteleuropa. Bd. 2(1-4). Stuttgart/ Jena: Gustav Fisher Verlag; 1988-1991.

33. Lau DCP, Christoffersen KS, Erkinaro J, Hayden B, et al. Multitrophic biodiversity patterns and environmental descriptors of subArctic lakes in northern Europe. Freshwater Biol. 2020; 00:1-19. https://doi.org/10.1111/fwb.13477

34. Lange-Bertalot H, Hofmann G, Werum M, Cantonati M. Freshwater Benthic Diatoms of Central Europe: Over 800 Common Species Used in Ecological Assessment. In: M. Cantonati, M.G. Kelly, H. Lange-Bertalot (Eds.). Schmitten-Oberreifenberg: Koeltz Botanical Books; 2017.

35. Maier DB, GälmanV, Renberg I, Bigler C. Using a decadal diatom sediment trap record to unravel seasonal processes important for the formation of the sedimentary diatom signal. J Paleolimnol. 2018;60:133-52.

36. Zgrundo A, Wojtasik B, Convey P, Majewska R. Diatom communities in the High Arctic aquatic habitats of northern Spitsbergen (Svalbard). Polar Biology. 2017;40(4):873-90.
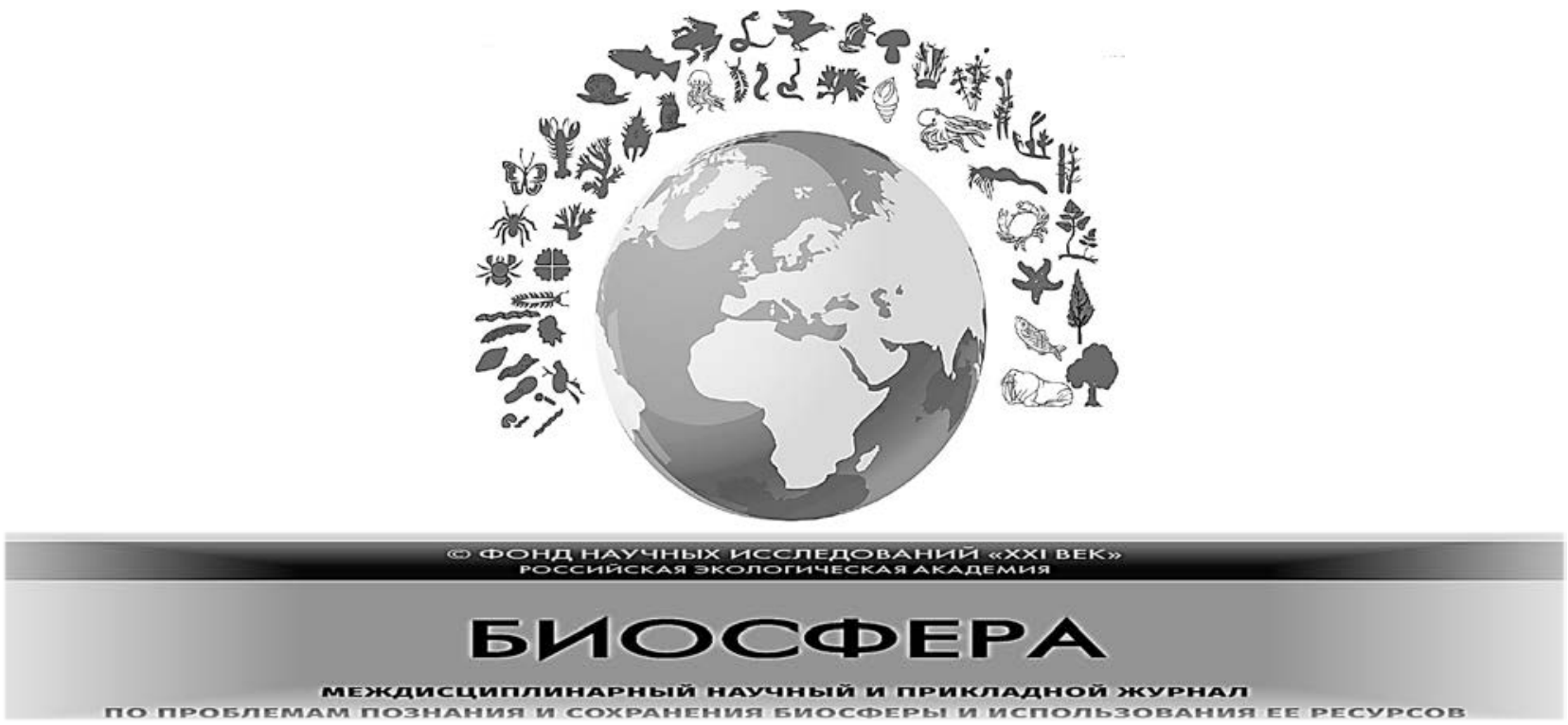